\title{
Effect of Kisspeptin on Serum Prolactin and Gonadotropins Levels in Balb-c Mice with Induced Chronic Stress
}

\author{
Ifra Ashraf1, Irum Rehman2, Khurram Irshad1 and Riffat Shafi1
}

\begin{abstract}
Objective: To determine and compare effects of kisspeptin on serum prolactin, luteinizing hormone and follicle stimulating hormone levels in Balb-c mice with and without exposure to chronic restraint stress.

Study Design: An animal experimental study.

Place and Duration of Study: Shifa College of Medicine / Shifa International Hospital Islamabad, in collaboration with National Institute of Health, Islamabad and Centre for Research in Experimental and Applied Medicine Laboratory, Army Medical College, Rawalpindi, from April 2014 to June 2015.

Methodology: Mice divided into three groups, each containing 30 mice. Control group (group A) received intraperitoneal injection of saline, group B was administered with intraperitoneal injection of saline and restrained stress, and group C was administered with both stress and kisspeptin $100 \mathrm{ng}$ daily for four weeks. Restraint stress was applied to groups B and $\mathrm{C}$ for three hours per day by immobilising individual mice in wire-mesh restrainers. At the end of four weeks blood sampling was done. Serum luteinizing hormones (LH), serum follicular stimulating hormone (FSH) and serum prolactin (PRL) were analysed by ELISA.

Results: Serum prolactin level increased in group B (stressed) and group C (stressed + kisspeptin treated) as compared to control group; and decreased in group C as compared to group B. Serum LH and FSH in group B was decreased as compared to control, and it was increased in group $\mathrm{C}$ as compared to control and group $\mathrm{B}$.

Conclusion: Administration of kisspeptin increases level of gonadotropins and reduces stress-induced hyperprolactinemia, which may improve fertility despite stress in animal.
\end{abstract}

Key Words: Kisspeptin, Prolactin, Gonadotropins and infertility.

\section{INTRODUCTION}

Stress is a condition which threatens homeostatic equilibrium of human body. ${ }^{1}$ Stress can be either acute or chronic in nature. Acute stress lasts for few minutes to hours, and chronic stress persists for several hours, days, weeks or months. ${ }^{2}$ The stress responses are necessary for survival and become harmful when these persist for a prolonged period of time. Acute stress is adaptive, and it involves multiple mediators, neurotransmitters, neuropeptides and hormones, while chronic stress is harmful and makes the individual vulnerable to various diseases. When body faces chronic or intense stress, stressors constantly prevent body system to return to the equilibrium. ${ }^{3}$

Long term stress can induce changes in multiple hormonal systems that can disrupt the stability of physiological systems like reproduction with negative impact on fertility. Stress hormones interact with hormones that influence fertility directly, such as

\footnotetext{
1 Department of Physiology, Shifa College of Medicine, Islamabad, Pakistan

2 Department of Physiology, Margalla Institute of Health Sciences, Rawalpindi, Pakistan

Correspondence: Dr. Ifra Ashraf, Department of Physiology, Shifa College of Medicine, Islamabad, Pakistan

E-mail:drifraashraf@gmail.com

Received: November 07, 2017; Accepted: September 13, 2018
}

gonadotropin releasing hormone $(\mathrm{GnRH})$, prolactin (PRL), luteinizing hormones (LH) and follicular stimulating hormone $(\mathrm{FSH}) .{ }^{4}$ Prolactin, one of stress hormones that is controlled by means of dopamine, is involved in different biological functions like lactation, reproduction, osmoregulation, and immunoregulation.5,6 Prolactin negatively modulates secretion of gonadal hormones including luteinizing hormone and follicle-stimulating hormone. ${ }^{7}$

During pregnancy, postpartum, and lactation, high levels of PRL inhibits LH secretion by inhibitory action of PRL on hypothalamic $\mathrm{GnRH}$ neurons. ${ }^{8}$ Kisspeptin, a peptide hormone discovered by scientists who belong to Hershey, Pennsylvania, home of the famous "Hershey Chocolate Kiss.9,10 Kisspeptin is major regulator of hypothalamic-pituitary-gonadal axis, leading to pubertal onset. GnRH neurons have kisspeptin receptor on them which releases luteinizing hormone and follicles stimulating hormone from $\mathrm{GnRH}$ neurons. ${ }^{10}$ Hyperprolactinemia and stress in mice reduced $\mathrm{GnRH}$, gonadotropins secretion and diminished kisspeptin expression. Kisspeptin administration restored gonadotropin secretion and ovarian cyclicity suggesting that kisspeptin neurons play a role in hyperprolactinemic anovulation. ${ }^{11,12}$

Hypothalamic pituitary gonadal axis is affected by acute stress which results in transient suppression of gonadotropin secretion. In stressful conditions, there 
may be alterations of hypothalamic kisspeptin system. So application of different forms of stress have obvious effect on kisspeptin system by changing level of kisspeptin mRNA levels and disturbing pulsatile release of $\mathrm{LH}$ in female rats. ${ }^{11,13}$

This study was designed to analyse the effects of kisspeptin on serum prolactin and gonadotrophic hormones in chronic stress.

\section{METHODOLOGY}

This study was approved by Institutional Review Board and Ethical Committee of Shifa College of Medicine and by Research Evaluation Unit of College of Physicians and Surgeons Pakistan. Ninety female adult 6-8 weeks old, BALB-c mice having weight $25 \pm 5$ grams were divided into three equal groups. The mice were kept in a room which was properly ventilated and daily photo period of 12 hours light-dark was ensured along with maintenance of room temperature $23 \pm 5^{\circ} \mathrm{C}$. Mice of the control group were placed in cages made of steel (1 1 1.5 feet). Mice of other groups were also placed in similar cages, but restraint stress was applied to these groups for three consecutive hours by immobilising individual mice in wire-mesh restrainers. Mice of control group A received daily intraperitoneal injections of $100 \mathrm{ng}$ normal saline for four weeks. Group B includes mice exposed to stress in a wire-mesh restrainer for three consecutive hours every day for four weeks. ${ }^{14,15}$ These mice received daily intraperitoneal injections of $100 \mathrm{ng}$ normal saline before stress. All mice of group C were exposed to stress in a mesh wire restrainer for three consecutive hours every day for four weeks. The stress was administered each day at random times to prevent habituation to the procedure. 16 These mice received daily intraperitoneal injections of $100 \mathrm{ng}$ kisspeptin before stress. At the end of four weeks, intracardiac blood sampling was done. Serum was separated, stored at $-70^{\circ} \mathrm{C}$ till further analyses. Serum $\mathrm{LH}$, serum $\mathrm{FSH}$, and serum prolactin were analysed by ELISA. Data was analysed by using SSPS version 17. In first step, we apply Shapiro-Wilk normality test to check the normality of the serum prolactin $(\mathrm{ng} / \mathrm{ml})$, serum $\mathrm{LH}(\mathrm{mlU} / \mathrm{ml})$, and serum $\mathrm{FSH}(\mathrm{ng} / \mathrm{ml})$.

Median and Interquartile Range was calculated. Statistical significance among control (A), Stress (B) and Stress + Kisspeptin (C) groups were determined by applying Kruskal-Wallis test. Statistical significance between two groups were determined by applying
Table II: Comparison of serum prolactin, serum LH and serum FSH among $\mathrm{A}, \mathrm{B}$ and $\mathrm{C}$ groups by Mann-Whitney test.

\begin{tabular}{l|c|c|c}
\hline Groups & $\begin{array}{c}\text { Serum Prolactin } \\
(\mathrm{ng} / \mathrm{ml})\end{array}$ & $\begin{array}{c}\text { Serum } \mathrm{LH}(\mathrm{mlU} / \mathrm{ml}) \\
(\mathrm{mlU} / \mathrm{ml})\end{array}$ & $\begin{array}{c}\text { Serum FSH } \\
(\mathrm{ng} / \mathrm{ml})\end{array}$ \\
\hline Control (A) & $<0.001$ & .044 & .012 \\
Stress(B) & .002 & .074 & .103 \\
Stress + Kisspeptin (C) & .034 & $<0.001$ & $<0.001$ \\
\hline Stress(B) & &
\end{tabular}

Mann-Whitney test. The $p$-value less than 0.05 was considered significant.

\section{RESULTS}

Median serum level of prolactin in control group A was $4.53(3.22) \mathrm{ng} / \mathrm{ml}$; in group B which was exposed to restrain stress, was $9.99(5.61) \mathrm{ng} / \mathrm{ml}$; and in group C which was treated with kisspeptin after stress, was $8.29(4.05) \mathrm{ng} / \mathrm{ml}$, which was statistically significant $(p<0.001)$. Median serum level of prolactin in group B was also raised in comparison with control group, which was statistically significant $(p<0.001)$. While comparing group $B$ with group $C$, median serum level of prolactin was decreased significantly in group $C(p=0.034)$.

Median serum level of luteinizing hormone in control group A was $22.90(30.10) \mathrm{mlU} / \mathrm{ml}$, in group B was 13.69 (18.55) $\mathrm{mlU} / \mathrm{ml}$, and 30.72 (34.78) $\mathrm{mlU} / \mathrm{ml}$, in group $\mathrm{C}$ which was statistically significant $(p=0.001)$. Median serum level of LH in group $B$ was significantly $(p=0.044)$ decreased as compared to control group A. Median serum level of $\mathrm{LH}$ was found to be increased in group $\mathrm{C}$ as compared to control group $A(p=0.074)$ which was not significant. While comparing group B with group C, serum $\mathrm{LH}$ level was significantly raised in group $\mathrm{C}$ $(p<0.001)$. Median serum level of follicular stimulating hormone in control group A was $83.48(33.50) \mathrm{ng} / \mathrm{ml}$; in group B, it was found to be $69.34(46.70) \mathrm{ng} / \mathrm{ml}$; and in group C, it was $95.06(28.70) \mathrm{ng} / \mathrm{ml}$, which was statistically significant $(p<0.001)$. It was significantly decreased in group $B(p=0.012)$ and increased in group $C$ as compared to control group $A(p=0.103)$; but increase was not significant. In comparison of group $B$ with group $\mathrm{C}$, serum $\mathrm{FSH}$ was found to be significantly raised in group $C(p<0.001)$.

\section{DISCUSSION}

Results of the current study showed that administration of exogenous kisspeptin in mice induced with chronic

Table I: Comparison of serum prolactin, $\mathrm{FSH}$, and $\mathrm{LH}$ in group A, B and $\mathrm{C}$ by Kruskal-Wallis test.

\begin{tabular}{|c|c|c|c|c|c|}
\hline Variables & $\begin{array}{c}\text { Group A (Control) } \\
\text { Median (IQR) }\end{array}$ & $\begin{array}{c}\text { Group B (Stress) } \\
\text { Median (IQR) }\end{array}$ & $\begin{array}{c}\text { Group C (Stress + Kisspeptin) } \\
\text { Median (IQR) }\end{array}$ & $\begin{array}{c}\text { Kruskal-Wallis Test } \\
\text { (Chi-Square) }\end{array}$ & $p$-value \\
\hline Serum Prolactin (ng/ml) & $4.53(3.22)$ & $9.99(5.61)$ & $8.29(4.05)$ & 23.501 & $<0.001$ \\
\hline Serum LH (mlU/ml) & $22.90(30.10)$ & $13.69(18.55)$ & $30.72(34.78)$ & 13.515 & 0.001 \\
\hline Serum FSH (ng/ml) & $83.48(33.50)$ & $69.34(46.70)$ & $95.06(28.70)$ & 16.484 & $<0.001$ \\
\hline
\end{tabular}

IQR: Interquartile range. P-value was obtained by Kruskal-Wallis test, $(p<0.05)$ was significant. 
stress through immobilisation, resulted in an increase in concentration of both serum luteinizing and follicle stimulating hormone. This is supported by a study conducted by Tovar et al. which showed that systemic intravenous injection of kisspeptin-10 elicited, significant rise in LH secretion in male rats with metabolic stress like fasting. ${ }^{17}$ Calley and Dhillo, conducted a study in which they administered kisspeptin-10 to healthy human male volunteers resulted in significant increase in LH release and a smaller increase in FSH release. Similarly, they took healthy female volunteers and administered them both kisspeptin- 10 and kisspeptin- 54 which acutely stimulated a gonadotropins secretion, with much more potency for stimulation of LH than $\mathrm{FSH} .18$ Castellano et al. took 30 days old male and female rats and divided in two groups. One group was subjected to metabolic stress by depriving them food for 72 hours with only access to tap water. One nmol of kisspeptin-10 per rat was administered by intracerebroventricular route. Animals injected with vehicle like $\mathrm{NaCl}$ served as controls. Results showed that kisspeptin was effective in inducing LH secretion significantly in fasted animals as compared to controls. 19 The results of their study are consistent with the result of this study.

There is considerable evidence in rats and humans that prolactin inhibits LH secretion, and this is likely to be the cause of infertility by elevated prolactin. Present study showed that administration of kisspeptin decreased concentration of prolactin, which was increased due to stress but this decrease in prolactin level was not so significant. Studies regarding correlation between kisspeptin and prolactin have revealed varying results and no such studies have been directed to determine effect of kisspeptin on raised level of serum prolactin. In the study by Sonigo et al., 31 mice were treated with PRL over 28 days and then observed for recovery of cycles. An additional group received PRL and daily intraperitoneal injections of $100 \mathrm{ng}$. Continuous infusion of prolactin subcutaneously in female mice resulting in hyperprolactinemia along with reduction in circulating level of $\mathrm{GnRH}$, LH, and FSH. Kisspeptin immunoreactivity was also reduced in hypothalamus in hyperprolactinemic mouse model. Administration of intraperitoneal injections of kisspeptin once daily into hyperprolactinemic mice for 20 days increased pituitary $\mathrm{LH}$ and FSH and circulating $\mathrm{GnRH} .20$ So the study by Sonigo et al. showed that hyperprolactinemia due to exogenous administration of prolactin in mice induces hypogonadotropic anovulation and that peripheral kisspeptin administration restores $\mathrm{GnRH}$, gonadotropins secretion, and ovarian cyclicity. Study results of Sonigo et al. are different from present study in a way that hyperprolactinemia in the former study is induced by exogenous administration of prolactin rather than hyperprolactinemia induced by chronic restrain stress, and showed that kisspeptin administration reverses anovulation by restoring the level of $\mathrm{GnRH}, \mathrm{LH}$, and FSH but this study did not show whether kisspeptin administration decreased raised prolactin or not.

\section{CONCLUSION}

On the basis of results obtained in this study, it is concluded that chronic stress causes an increase in level of serum prolactin and decrease in levels of serum luteinizing and follicle stimulating hormones. Administration of kisspeptin leads to significant increase in stress-induced decrease in serum luteinizing and follicular stimulating hormone levels and reduces hyperprolactinemia.

Disclosure: This is dissertation-based study.

\section{REFERENCES}

1. Chrousos GP. Stress and disorders of the stress system. Nat Rev Endocrinol 2009; 5:374-81.

2. Dhabhar FS. A hassle a day may keep the doctor away: Stress and the augmentation of immune function. Integr Comp Biol 2002; 42:556-64.

3. Moisan MP, Le Moal M. Overview of acute and chronic stress responses. Med Sci 2012; 28:612-7.

4. Campagne DM. Should fertilization treatment start with reducing stress? Hum Reprod 2006; 21:1651-8.

5. Freeman ME, Kanyicska B, Lerant A, Nagy G. Prolactin: structure, function, and regulation of secretion. Physiol Rev 2000; 80:1523-631.

6. Bole-Feysot C, Goffin V, Edery M, Binart N, Kelly PA. Prolactin $(P R L)$ and its receptor: actions signal transduction pathways and phenotypes observed in PRL receptor knockout mice. Endocr Rev 1998; 19:225-68.

7. Serri O, Chik CL, Ehud Ur, Ezzat S. Diagnosis and management of hyperprolactinemia. CMAJ 2003; 169:575-81.

8. Milenkovi L, Angelo GD, Kelly PA, Weiner RI. Inhibition of gonadotropins hormone-releasing hormone release by prolactin from GT1 neuronal cell lines through prolactin receptors. Proc Natl Acad Sci 1994; 91:1244-7.

9. Oakley AE, Clifton DK, Steiner RA. Kisspeptin signaling in the brain. Endocrine Rev 2009; 30:713-43.

10. Jayasena CN, Nijher GMK, Comninos AN, Abbara A, Januszewki A, Vaal ML, et al. The effects of Kisspeptin-10 on reproductive hormone release show sexual dimorphism in humans. J Clin Endocrinol Metab 2011; 96:1963-72.

11. Pinilla L, Aguilar E, Dieguez C, Millar RP, Tena-Sempere M. Kisspeptins and reproduction: Physiological roles and regulatory mechanisms. Physiol Rev 2012; 92:1235-316.

12. Sonigo C, Bouilly J, Carré N, Tolle V, Caraty A, Tello J, et al. Hyperprolactinemia-induced ovarian acyclicity is reversed by kisspeptin administration. J Clin Invest 2012; 122:3791-5.

13. Babygirija R, Zheng J, Ludwig K, Takahashi T. Central oxytocin is involved in restoring impaired gastric motility following chronic repeated stress in mice. Am J Physiol Regul Integr Comp Physiol 2010; 298:157-65.

14. Kumar RS, Narayanan SN, Nayak S. Ascorbic acid protects against restraint stress-induced memory deficits in Wistar rats. Clinics (Sao Paulo) 2009; 64:1211-7. 
15. Capoccia S, Berry A, Bellisario V, Vacirca D, Ortona E, Alleva E, et al. Quality and timing of stressors differentially impact on brain plasticity and neuroendocrine-immune function in mice. Neural Plast 2013; 2013:971817.

16. Tovar S, Vazquez MJ, Navarro VM, Fernandez-Fernandez R, Castellano JM, Vigo E, et al. Effects of single or repeated intravenous administration of kisspeptin upon dynamic $\mathrm{LH}$ secretion in conscious male rats. Endocrinology 2006; 147: 2696-704.

17. Calley JL, Dhillo WS. Effects of the hormone kisspeptin on reproductive hormone release in humans. Adv Biol 2014; 512650 .
18. Castellano JM, Navarro VM, Fernandez-Fernandez $R$, Nogueiras R, Tovar S, Roa J, et al. Changes in hypothalamic KiSS-1 system and restoration of pubertal activation of the reproductive axis by kisspeptin in undernutrition. Endocrinology 2005; 146:3917-25.

19. Sonigo C, Bouilly J, Carre N, Tolle V, Caraty A, Tello J, et al. Hyperprolactinemia-induced ovarian acyclicity is reversed by kisspeptin administration. J Clin Invest 2012; 122:3791-5

20. Jayasena CN, Comninos AN, Narayanaswamy S, Bhalla $S$, Abbara A, Ganiyu-Dada Z, et al. Acute and chronic effects of kisspeptin-54 administration on $\mathrm{GH}$, prolactin and $\mathrm{TSH}$ secretion in healthy women. Clin Endocrinol 2014; 81:891-8.

.......... 